\title{
LETTER TO READERS
}

\section{Dear Readers:}

Seminars in Neurosurgery has been publishing review articles of reference for 15 years. Skull Base: An Interdisciplinary Approach has been publishing original articles for the past 12 years. Both serve the same community; in fact, many of you subscribe to both.

We have therefore decided to merge these two journals. This has several advantages:

- Skull Base is indexed in Current Contents/ISI and will be indexed in Pubmed Central shortly, which was not the case with Seminars in Neurosurgery. Thus you will have easier access to the reviews, and our authors will have better exposure.

- By combining review articles and original articles we aim to offer a more complete read, and better serve your intellectual curiosity and continuing education objectives.

- By merging the journals and thus expanding the scope of articles accepted, we are establishing the basis for the future growth of the journal, which will lead to an expanded page budget and frequency.

This last double issue of Seminars in Neurosurgery, "Pain Management for the Neurosurgeon: Part 2," is the close of a respected publication and we wish here to express our gratitude to Dr. Winfield S. Fisher III, the Editor in Chief, for all he has done for this journal. It will be, in many ways, continued in 2005 by the reviews on cerebral revascularization, guest edited by Dr. John Wanebo, to be published in the first issues of Skull Base.

We look forward to serving you in 2005, with the newly expanded edition of Skull Base. Please contact me should you have comments or suggestions regarding this journal's focus and future.

Sincerely, Daniel Schiff, M.D. Vice President and Publisher, Journals ${ }^{1}$

Pain Management for the Neurosurgeon: Part 2; Editor in Chief, Winfield S. Fisher III, M.D.; Guest Editor, Kim J. Burchiel, M.D., F.A.C.S. Seminars in Neurosurgery, volume 15, numbers 2/3, 2004. Address for correspondence and reprint requests: Daniel Schiff, M.D., Thieme Medical Publishers, Inc., 5th Fl., 333 Seventh Ave., New York, NY 10001. E-mail: dschiff@thieme.com. ${ }^{1}$ Thieme Medical Publishers, Inc., New York, New York. Copyright (C) 2004 by Thieme Medical Publishers, Inc., 333 Seventh Avenue, New York, NY 10001, USA. Tel: +1(212) 584-4662. 15268012,p;2004,15,02/03,111,111,ftx,en;sns00192x. 